\title{
Examining the Knowledge Level of the Nurses and Midwives Had Neonatal Resuscitation Program (NRP) Practitioner Training Course
}

\author{
Senay Cetinkaya $\mathbb{D}^{\prime}$, Burcu Turkoglu², Emra Dogan ${ }^{2}$, Mustafa Kara $\mathbb{D}^{3}$ \\ 'Child Health and Diseases Nursing, Department of Nursing, Çukurova University, Adana, Turkey; ${ }^{2}$ Health Sciences Institute, Çukurova University, \\ Adana, Turkey; ${ }^{3}$ Afșin Health College, Kahramanmaraș Sütçü Imam University, Kahramanmaraș, Turkey \\ Correspondence: Senay Cetinkaya, Faculty of Health Sciences, Department of Nursing, Child Health and Diseases Nursing, Çukurova University, \\ Adana, 0 I I30, Turkey, Tel +90322 38864 84, Fax +90322 33869 70, Email senayg_202@hotmail.com
}

Background and Purpose: The aim of this study was to investigate the knowledge level of nurses and midwives about the level of knowledge about neonatal resuscitation and the effect of education on knowledge levels.

Methods: The research was applied in January 2016 to the nurses and midwives who worked in neonatal intensive care units, gynecology and maternity wards at Cukurova University Balcalı Hospital, Adana Numune Training and Research Hospital, Adana Maternity and Children Diseases Hospital, and had received Neonatal Resuscitation Program practitioner training course. All of the target populations were included in the research before the sample was determined. Data were collected using a questionnaire form consisting of 40 questions including sociodemographic information and knowledge level related to NRP.

Results: It was determined that the nurses and midwives answered the questions correctly related to oxygen usage (98.1\%) and all the things that should be conducted in order to prevent heat loss in baby (98.1\%). It was determined that NRP knowledge points of nurse/ midwives were intermediate level as $23.06 \pm 3.47$ (min: 12; max: 30) and most of the participants (37\%) had got NRP course in the last 4-5 years. There was a statistically significant difference between participating time to NRP practitioner training course and working years $(\mathrm{p}<0.05)$.

Implications for Practice: Systematic repetition of knowledge and skills through in-service training programs is important, as it will lead to a reduction of mortalities of newborns.

Implications for Research: It was observed that the knowledge points were quite good considering that the participants of the NRP practitioner-training course had taken the course in the last $4-5$ years.

Keywords: education, midwife, neonatal, nurse, resuscitation knowledge level

\section{Introduction}

A newborn baby or newborn is a child under the age of 28 days. During the first 28 days of life, the risk of dying of the newborn is the highest. In 2017, $47 \%$ of child deaths below the age of 5 were among the newborn infants - while that rate had been $40 \%$ in $1990 .{ }^{1}$ Every newborn baby has to complete the transition to extrauterine successfully in order to survive and then to maintain his/her growth. ${ }^{2}$ Infant mortality, which is defined as the probability of dying in the first year of life, is a key criterion to compare the health status and social well-being of societies. ${ }^{3}$ Four million infants with an estimated rate die each year in the first 4 weeks of life (in newborn period). ${ }^{4}$ Almost all (99\%) of these deaths occur in low- and middle-income countries. ${ }^{5}$ The main causes of neonatal deaths in 2016 were prematurity and low birth weight, infections, asphyxia, and birth trauma. The majority of all neonatal deaths (75\%) occur in the first week of life and within the first 24 hours about 1 million newborns die. ${ }^{1}$ Most of the newborns are not implied timely and correctly resuscitation. With the widespread use of appropriate animation techniques, thousands of newborns will be prevented from being killed or paralyzed every year. The main objective of the NRP training is to provide the health worker with the necessary knowledge and experience to provide the best care to the newborns in the delivery room and to ensure the proper use of 
this experience in the postnatal delivery room in rural and urban hospitals. ${ }^{6}$ The term resuscitate, which means revitalization in Latin, refers to the term neonatology which is used in two areas, such as the need for urgent approaches when a newborn is in the hospital under follow-up and treatment and while making resuscitation of a newborn with respiratory and cardiac arrest. $^{7}$

In all the centers where delivery is made, the materials required during resuscitation should be made available, the whole team should move within a specific implementation plan and should be familiar with the resuscitation practices since approximately $1 / 10$ of the babies may require revitalization in the first minutes following birth. ${ }^{8}$ A person with the knowledge and ability to fully practice neonatal resuscitation should be present at every birth. ${ }^{9}$ If a full revitalization is needed, additional health care workers with the necessary training will be required. ${ }^{10}$ Nurses, midwives and physicians in the delivery room must gain the necessary knowledge and experience in newborn resuscitation. ${ }^{11}$

The main purpose of resuscitation in the delivery room is to provide adequate ventilation, oxygenation and cardiac output to deliver the required amount of oxygen to the brain, heart and other vital organs. ${ }^{12}$ The results of interventions in the first few minutes of life have a direct impact on the quality of life and have consequences for a whole life. ${ }^{13}$

Staff training conducted through a training program in the United States is called the Neonatal Resuscitation Program (NRP), which includes educational materials approved by the American Heart Association (AHA) and the American Children's Academy (AAP). ${ }^{14}$ Since 1996, NRP courses are being made on a regular basis in Turkey with the cooperation of the Ministry of Health and Neonatology Association. ${ }^{15}$ The first Neonatal Intensive Care Unit (NICU) course in Turkey was given to nurses from various provinces in Istanbul. The aim of this course is to improve the quality of nursing care in the complex and sensitive nature of neonatal nursing. This NICU course has been developed to identify the developments that may be involved in the care of newborns at risk, to examine the problems and trends affecting newborn patients, and to provide the necessary training and tools to improve the quality of care. ${ }^{16}$

The aim of this study is to determine the knowledge level of nurses and midwives in Adana Province on neonatal resuscitation and to investigate the effect of NRP education on their knowledge levels. Studies in this area are usually given an education and then measure its effect. However, no study has been conducted to the level of knowledge scores and the level of education. Although these courses are organized in Adana, it is a unique study because there is no study examining the level of knowledge of the educated people.

\section{Methods}

The research was applied to 151 nurses/midwives in January 2016 to the nurses and midwives who work in neonatal intensive care units, gynecology and maternity wards at Cukurova University Balcalı Hospital, Adana Numune Training and Research Hospital and Adana Maternity and Children Diseases Hospital, and who had received Neonatal Resuscitation Program (NRP) practitioner training course. The target population has been included in the study without sampling. The study was conducted with 105 nurses and midwives who accepted to participate in the research. Participation rate was $67.5 \%$.

Training related to NRP (visual presentation, training book and practical training on the model) has been arranged 12 times in Adana Province and this issue has been included in the in-service training plan for the regulation of 81 provinces by the Ministry of Health.

In order to carry out the study, Cukurova University Ethics Committee Approval and approval from T.C. Ministry of Health, Public Hospitals Authority in Adana Province in Turkey were received to perform the work in public hospitals.

The data are collected by a questionnaire consisting of 40 questions prepared by the researchers and reviewed from the related literature. The first 10 questions are socio-demographic questions. The total point of 30 questions, which are important for theoretical and practical is 30 . The correct answers to the twelve questions are arranged as the wrong option for the distraction. Table 1 consists of the "true, false and I do not know" answers to the questions that are seen in the questions. Dark/bold written questions are the correct answers to the questions. Created questions are prepared by taking the opinions of the relevant experts in the field. A pre-application of the questionnaire was conducted to the participants, and the pre-applications of 10 of these participants were not included in the study. Percentage distributions, $t$ test and chisquare analysis were used to evaluate the data. This study was supported by Çukurova University Individual Research Project (number: TSA-2017-7740). 
Table I Distribution of the Knowledge of Nurses and Midwives of Situations Regarding the Neonatal Resuscitation Program (NRP)

\begin{tabular}{|c|c|c|c|c|c|c|}
\hline \multirow[t]{2}{*}{ Questions Related to NRP } & \multicolumn{2}{|c|}{ True } & \multicolumn{2}{|c|}{ False } & \multicolumn{2}{|c|}{$\begin{array}{l}\text { I Do } \\
\text { Not } \\
\text { Know }\end{array}$} \\
\hline & $\mathbf{n}$ & $\%$ & $\mathbf{n}$ & $\%$ & $\mathbf{n}$ & $\%$ \\
\hline $\begin{array}{l}\text { Careful determination of risk factors during pregnancy and puerperium allows the identification of all } \\
\text { babies who will need resuscitation. }\end{array}$ & 83 & 79 & 15 & 14.3 & 7 & 6.7 \\
\hline The alveoli in the lungs of the baby before conception is narrowed and filled with air. & 31 & 29.5 & 69 & 65.7 & 5 & 4.8 \\
\hline $\begin{array}{l}\text { If a baby does not start breathing in response to a tactile stimulus, it should be assumed that it is in } \\
\text { secondary apnoea and positive pressure ventilation should be provided. }\end{array}$ & 96 & 91.4 & 6 & 5.7 & 3 & 2.9 \\
\hline Ensuring adequate ventilation usually results in an increase of rapid heart rate. & 86 & 81.9 & 16 & 15.2 & 3 & 2.9 \\
\hline Animation must be delayed until the Ist minute Apgar Score is received. & 37 & 35.2 & 62 & 59.2 & 6 & 5.7 \\
\hline $\begin{array}{l}\text { At least one health care provider should attend each birth and be responsible for the care of the } \\
\text { newborn. }\end{array}$ & 82 & 78.1 & 20 & 19 & 3 & 2.9 \\
\hline If a depressed baby is not expected at birth, animation devices should not be kept ready for use. & 15 & 14.3 & 86 & 81.4 & 4 & 3.8 \\
\hline $\begin{array}{l}\text { Preventing heat loss of babies is very important. For this purpose a radiant heater should be used, wet } \\
\text { towels should be removed and the baby should not be wrapped with a blanket or towels when the baby } \\
\text { is under a radiant heater. }\end{array}$ & 95 & 90.5 & 8 & 7.6 & 2 & 1.9 \\
\hline $\begin{array}{l}\text { If a very low birth weight preterm infant is expected, a radiant heater should be turned on, the baby } \\
\text { should be wrapped with a polyethylene plastic cover to prevent heat loss after birth and a preheated } \\
\text { transport incubator should be used. }\end{array}$ & 103 & 98.1 & 0 & 0 & 2 & 1.9 \\
\hline $\begin{array}{l}\text { An additional tactile stimulus to stimulate the breathing of the newborn is to pat the soles of the feet or } \\
\text { pat the newborn on the back. }\end{array}$ & 95 & 90.5 & 10 & 9.5 & 0 & 0 \\
\hline It is not always necessary to have different sizes of masks on our way to delivery. & 19 & 18.1 & 85 & 81 & I & 1 \\
\hline $\begin{array}{l}\text { A baby who is depressed or has meconium in amniotic fluid does not need aspiration of trachea with an } \\
\text { endotracheal tube. }\end{array}$ & 12 & 11.4 & 92 & 87.6 & 1 & I \\
\hline $\begin{array}{l}\text { If a newborn is covered with meconium, taking good breathing, with a good muscle tone and a heart rate } \\
\text { of } 120 \text { beats/min, and the mouth and nose are aspirated by a pus or aspiration catheter. }\end{array}$ & 97 & 92.4 & 5 & 4.8 & 3 & 2.8 \\
\hline As the baby's nose and mouth are aspirated, as a rule, firstly the mouth and then the nose is aspirated. & 93 & 88.6 & 8 & 7.6 & 4 & 3.8 \\
\hline $\begin{array}{l}\text { An automatically swollen balloon connected to a source of oxygen provides ventilation with } 90-100 \% \\
\text { oxygen. }\end{array}$ & 76 & 72.4 & 17 & 16.2 & 12 & 11.4 \\
\hline $\begin{array}{l}\text { Oxygen should be considered as a drug, using more or less than necessary may have negative } \\
\text { consequences. }\end{array}$ & 103 & 98.1 & 1 & I & 1 & I \\
\hline The most important and effective step in neonatal resuscitation is to ventilate the lungs. & 97 & 92.4 & 6 & 5.7 & 2 & 1.9 \\
\hline $\begin{array}{l}\text { When ventilating the baby, the rate of positive pressure ventilation should be maintained between } 40 \text { and } \\
60 \text { breaths/minute. }\end{array}$ & 97 & 92.4 & 5 & 4.8 & 3 & 2.9 \\
\hline $\begin{array}{l}\text { Although positive pressure ventilation is performed for } 30 \text { seconds, if the baby's heart rate is below } 60 \\
\text { beats per minute, a chest compression is started and intubation can be considered. }\end{array}$ & 97 & 92.4 & 7 & 6.4 & 1 & I \\
\hline In chest compression, the thumb technique is generally preferred. & 97 & 92.4 & 5 & 4.8 & 3 & 2.9 \\
\hline The ventilation rate should be I compression to 3 ventilations within 2 seconds for a chest compression. & 66 & 62.9 & 39 & 37.1 & 0 & 0 \\
\hline $\begin{array}{l}\text { It is convenient and safe to stop compression and ventilation as soon as a newborn with chest } \\
\text { compression achieves a sufficient spontaneous heart rate. }\end{array}$ & 71 & 67.6 & 30 & 28.6 & 4 & 3.8 \\
\hline For infants weighing less than 1000 grams, the endotracheal tube should be $2.5 \mathrm{~mm}$ in internal diameter. & 64 & 61 & 34 & 32.4 & 7 & 6.7 \\
\hline $\begin{array}{l}\text { The laryngoscope knife number, which is preferred in newborns, is } 00 \text { in term, in preterm infants is } 0 \text {, } \\
\text { and in preterm infants it is } I .\end{array}$ & 18 & 17.1 & 71 & 67.6 & 16 & 15.2 \\
\hline No more than 30 seconds should be spent to complete endotracheal intubation. & 75 & 71.4 & 17 & 16.2 & 13 & 12.4 \\
\hline Less than I\% of babies who need animation need adrenaline as medication. & 83 & 79 & 15 & 14.3 & 7 & 6.7 \\
\hline Adrenaline reduces blood pressure and heart contractions. & 31 & 29.5 & 69 & 65.7 & 5 & 4.8 \\
\hline $\begin{array}{l}\text { There is a risk that the adrenaline from the endotracheal tube will be inadequately absorbed from the } \\
\text { lungs. }\end{array}$ & 66 & 62.9 & 20 & 19 & 19 & 18.1 \\
\hline Intravenous fluids should be given to preterm infants very quickly. & 8 & 7.6 & 95 & 90.5 & 2 & 1.9 \\
\hline $\begin{array}{l}\text { An oximeter should be used and/or arterial blood gas should be measured to ensure that an infant with } \\
\text { adequate resuscitation is well oxygenated. }\end{array}$ & 99 & 94.3 & 5 & 4.8 & I & 1 \\
\hline
\end{tabular}

Note: Dark/bold written questions are the correct answers to the questions. 
Table 2 Examining the Time of Attendance at an NRP Practitioner Training Course and Mean Knowledge Points of Nurses/Midwives

\begin{tabular}{|l|c|c|c|}
\hline Time of Attendance at NRP Course & Number of People & Knowledge Points & P \\
\hline 0-6 months & 14 & $\mathbf{2 3 . 9 \pm 2 . 8}$ & 0.33 \\
6 months-I year & 22 & $23.4 \pm 4.5$ & 0.33 \\
I-3 year & 32 & $23.3 \pm 3.4$ & 0.33 \\
4-5 year & 37 & $\mathbf{2 2 . 2 \pm 3 . 4}$ & 0.33 \\
Total & 105 & $23.0 \pm 3.4$ & 0.33 \\
\hline
\end{tabular}

Note: Bold values is written to draw attention to the highest and lowest scores.

\section{Results}

One hundred and two of the participants (97.1\%) were female. Considering the educational background, $7.6 \%$ of them graduated from medical vocational high school, $22.9 \%$ of them had associate degree, $62.9 \%$ of them had bachelor's degree and $1.9 \%$ of them had master's degrees, respectively. Sixty-two (59\%) of the participants were working in the neonatal intensive care units and $28(26.7 \%)$ of them were working in the delivery rooms. It was determined that $14 \%$ of the participants had that course in the last 0-6 months, $22 \%$ of the participants had it in the last 6 months- 1 year, $32 \%$ of them had it in the last $1-3$ years, and $37 \%$ of the participants had it in the last $4-5$ years.

The distribution of questions about nurse/midwives for NRP is shown in Table 1. Writings in bold are right answers. Nurses/midwives answered correctly the most important and effective intervention in neonatal revitalization (98.1\%) and questions about oxygen use (98.1\%) (Table 1).

The knowledge mean score of the nurses-midwives is $23.06 \pm 3.47$ (min: 12; max: 30). Table 2 shows the time for attending to the NRP practitioner training course and the mean of the knowledge points. No statistically significant difference was found between the time of attendance to the NRP practitioner training course and the mean score of knowledge $(\mathrm{p}>0.05)$.

A significant difference was found between nurse-midwives' attendance time to the NRP practitioner training course and the study year $(\mathrm{p}<0.05)$ (Table 3 ); and between age and time of participation in NRP practitioner training course $(\mathrm{p}<0.05)$ (Table 4).

Table 5 shows the ages and knowledge scores of nurses/midwives participating in the NRP practitioner training course.

One-way analysis of variance (ANOVA) between nurse/midwives and NRP knowledge points is significant $(\mathrm{p}<0.05)$.

Difference is significant between the age of nurses/midwives and the right answers given to question:

Preventing heat loss of babies is very important. For this purpose, a radiant heater should be used, wet towels should be removed and baby should not be wrapped with a blanket or towels when the baby is under a radiant heater. $(\chi 2=20.002$, $\mathrm{p}=0.003, \mathrm{p}<0.05)$

Table 3 Examining the Time of Attendance at an NRP Practitioner Training Course and Distribution of Working Time of Nurses/ Midwives

\begin{tabular}{|c|c|c|c|c|c|c|}
\hline \multirow[t]{2}{*}{ Time of Attendance at NRP Course } & \multicolumn{5}{|c|}{ Working Time of Nurses/Midwives } & \multirow[t]{2}{*}{ Total } \\
\hline & Less Than I Year & I-5 Years & 6-15 Years & 16-20 Years & More Than 20 Years & \\
\hline $0-6$ months & 2 & 7 & 3 & 2 & 0 & 14 \\
\hline 6 months-I year & 0 & 12 & 6 & 1 & 3 & 22 \\
\hline $\mathrm{I}-3$ years & 0 & 10 & 10 & 5 & 7 & 32 \\
\hline $4-5$ years & 0 & 4 & 14 & 12 & 7 & 37 \\
\hline Total & 2 & 33 & 33 & 20 & 17 & 105 \\
\hline
\end{tabular}

Note: $\chi^{2}=33.769, \mathrm{df}=12, \mathrm{p}=0.001, \mathrm{p}<0.05$. 
Table 4 Examining the Time of Attendance at an NRP Practitioner Training Course and Distribution of the Ages of Nurses/Midwives

\begin{tabular}{|c|c|c|c|c|c|c|c|c|c|c|}
\hline \multirow{3}{*}{$\begin{array}{l}\text { Time of Attendance at NRP } \\
\text { Course }\end{array}$} & \multicolumn{8}{|c|}{ Age Groups of Nurses/Midwives } & \multirow{3}{*}{$\begin{array}{c}\text { Total } \\
\mathbf{n}\end{array}$} & \multirow[b]{3}{*}{$\%$} \\
\hline & \multicolumn{2}{|c|}{ 18-25 Years } & \multicolumn{2}{|c|}{ 26-35 Years } & \multicolumn{2}{|c|}{ 36-45 Years } & \multicolumn{2}{|c|}{ Older Than 45} & & \\
\hline & $\mathbf{n}$ & $\%$ & $\mathbf{n}$ & $\%$ & $\mathbf{n}$ & $\%$ & $\mathbf{n}$ & $\%$ & & \\
\hline $0-6$ months & 5 & 35.7 & 8 & 57.1 & 1 & 7.1 & 0 & 0 & 14 & 100 \\
\hline 6 months-I year & 7 & 31.8 & 10 & 45.5 & 4 & 18.2 & I & 4.5 & 22 & 100 \\
\hline I-3 years & 3 & 9.4 & 16 & 50.0 & 10 & 31.2 & 3 & 9.4 & 32 & 100 \\
\hline $4-5$ years & 0 & 0 & 16 & 43.2 & 20 & 54.1 & I & 2.7 & 37 & 100 \\
\hline Total & 15 & 14.3 & 50 & 47.6 & 35 & 33.3 & 5 & 4.8 & 105 & 100 \\
\hline
\end{tabular}

Note: $\chi^{2}=27.167, \mathrm{df}=9, \mathrm{p}=0.001, \mathrm{p}<0.05$.

Table 5 Examining the Ages and Knowledge Points of Nurses/Midwives Who Participated at an NRP Practitioner Training Course

\begin{tabular}{|l|c|c|c|}
\hline $\begin{array}{l}\text { Age Groups of Nurses/ } \\
\text { Midwives }\end{array}$ & $\mathbf{n}$ & NRP Knowledge Points & P \\
\hline $18-25$ years & 15 & $23.9 \pm 3.9$ & 0.089 \\
$26-35$ years & 50 & $22.6 \pm 3$ & 0.089 \\
$36-45$ years & 35 & $22.8 \pm 3.6$ & 0.089 \\
Older than 45 years & 5 & $26.4 \pm 2.7$ & 0.089 \\
Total & 105 & $23.0 \pm 3.4$ & 0.089 \\
\hline
\end{tabular}

There was not a significant difference between the education level and the answers given to the question of "Animation must be delayed until the 1st minute Apgar Score is received" $(\chi 2=0.016, p=0.898, p>0.05)$.

There could not be found a significant difference between the time of attendance to course and the answers given to "The alveoli in the lungs of the baby before conception is narrowed and filled with air" question $(p>0.05)$.

There was not a significant relationship between education level and answers given to the question of "It is convenient and safe to stop compression and ventilation as soon as a newborn with chest compression achieves sufficient spontaneous heart rate." $(\chi 2=0.408, \mathrm{p}=0.523, \mathrm{p}>0.05)$.

It could not be determined a significant relationship between working wards and answers given to "Ensuring adequate ventilation usually results in an increase of rapid heart rate" question $(\mathrm{p}>0.05)$.

One-way analysis of variance (ANOVA) between nurses/midwives and NRP knowledge points was not significant $(\mathrm{p}>0.05)$.

Considering education level, working wards and working times of nurses/midwives, it could not be a found a significant difference between their knowledge points $(\mathrm{p}>0.05)$.

\section{Discussion}

Simple measures such as protection from hypothermia, proper handling of the head, aspiration and the need for respiratory support may lead to significant changes in the disease and mortality rates of the newborn. ${ }^{14,17}$

Nurses/midwives answered questions related to the most important and effective intervention in neonatal revitalization, things to do for preventing heat loss $(98.1 \%)$, and oxygen use $(98.1 \%)$ correctly. Ninety-three $(88.6 \%)$ of the participants gave the correct answer to question "as the baby's nose and mouth are aspirated, as a rule at first mouth and then nose is aspirated". (Table 1). The correct answers from nurses/midwives are very pleasing.

The primary cause of neonatal arrest is almost always respiratory. Therefore, a 3:1 compression: ventilation rate is recommended. However, if the cause of the arrest is known to be of cardiac origin; 15:2 compression-ventilation may be applied. ${ }^{18,19}$ 
Sixty-six (62.9\%) of the nurses/midwives gave the wrong answers for given to "The ventilation rate should be 1 compression to 3 ventilations within 2 seconds for chest compression" question (Table 1) (The question was prepared as a distractor and the answer would be wrong). Resuscitation is a procedure that requires constant training. However, it is important to make good education as well as theoretical education on this subject. ${ }^{20}$ Three basic conditions are necessary for learning to occur: practice, motivation, and reinforcement. ${ }^{16}$ The NRP was updated, and it would be good to plan training with this new knowledge, particularly with regard to chest compressions.

In a large series of cases in pediatric age group, it was found that when the cause of arrest was non-cardiac aetiology, respiratory distress was higher with chest compression and a higher chance of life with chest pressure alone. In cases with cardiac causes, no difference was observed in the resuscitation results. Therefore, in cases where the cause of arrest is mostly due to asphyxia, with consideration of ventilation based on chest compression, non-health rescuers who do not want to breathe or mouth resuscitation should prefer to perform resuscitation with chest compressions. $^{21,22}$

There are two ways to assess the effectiveness of the Neonatal Resuscitation Program courses. The first one is to measure the impact on the nature of birth care in the region, and the second is to investigate the knowledge and/or experiences of the course participants with post-course evaluation inquiries. ${ }^{11}$

No significant difference was found between the time to attend the NRP practitioner training course and the mean score of knowledge $(\mathrm{p}>0.05)$. However, it has been seen that the knowledge point averages of the participants in the course of the course are higher as time goes by. It was determined that NRP knowledge points of nurse/midwives were intermediate level as $23.06 \pm 3.47$ (min: 12; max: 30) and most of the participants (37\%) had got NRP course in the last 4-5 years (Tablo 2). Studies have shown that simple knowledge-skills deteriorate within 1-6 months of training. ${ }^{20}$ Although the average of the passing time is higher, being knowledge points as intermediate may be interpreted as good. The systematic repetition of knowledge and skills with in-service training programs on NRP will be effective in keeping the information up-to-date. Therefore, it is recommended to arrange these trainings at certain intervals. Approximately $1 /$ 3 of nurses/midwives took this course 4-5 years ago (Table 2). However, nurses and midwives need to participate in refresher courses every two years in order to be able to keep their knowledge and skills up to date, to be successful and to maintain their status as practitioners according to international standards. ${ }^{23}$ In the study of Uçan and Alparslan, approximately $19.2 \%$ of the midwives stated that they attended the NRP in the post-graduate period. Similar results were observed with the study. In the study of Uçan \& Alparslan, it was revealed that the majority of the midwives had insufficient knowledge about neonatal resuscitation. However, their study did not work with midwives, especially those who received NRP training. ${ }^{12}$ In the study of Ak1ll et al conducted with physicians, it was stated that although they had been trained in the last 1 year, use of that information is limited in practical terms. Therefore, they emphasized the development of a training program, including the Emergency Medicine System, instead of a training program, which is only offered by courses. Both in daily practice and in the CPR group who are dealing with cardiopulmonary resuscitation (CPR), the education of the group of physicians who are not frequent and should be more frequent and practical. ${ }^{20}$ In the study of Trevisanuto et al it was emphasized that after the NRP course, the participants' knowledge level decreased significantly at the end of 6 months and it should be renewed before the end of the two-year period. ${ }^{17}$ In the study of Duran et al, it was determined that the knowledge level decreased in the six months after the course and the lessons taught in the course were partially remembered although the level of knowledge of the participants increased significantly after the NRP course. This information revealed that the NRP course should be repeated one year after the first course, especially before the end of the two-year term. ${ }^{11}$ In the study, no significant difference was determined in knowledge score according to months, ages, educational status, clinics and working years after the NRP course $(p>0.05)$. Similarly, in the Çınar and Güney study, there were no statistically significant differences between nurses' level of education and working years and knowledge about neonatal resuscitation. ${ }^{24}$

It should be kept in mind that babies who require resuscitation may have a risk of worsening again after their vital signs return to normal and should be followed carefully. Low blood glucose levels increase the risk of brain damage. ${ }^{25}$ Increased glucose levels after hypoxia or ischemia have been reported to have a protective effect, in contrast to side effects. $^{26,27}$ 
Nurse-Midwives should develop their knowledge and skills about NRP with in-service training programs, and inservice training should be repeated periodically after the training to keep the information updated.

According to World Health Organization estimates, five million newborns are lost every year; approximately $20 \%$ of them are due to birth asphyxia, and therefore, one million newborns can be saved by successful resuscitation per year. ${ }^{11}$ The 2013 infant mortality rate was 10.2 per thousand in Turkey, and it is 13.9 per thousand in Adana. ${ }^{28}$ It is needed that NRP courses should be done systematically in Adana Province.

Every newborn has the right to receive adequate and proper care. This right can be met by the availability of suitable equipment and trained health personnel in the delivery room. The NRP program, which aims at "Everyone in the delivery room", will contribute significantly to the reduction of newborn mortality and the sequelae of asphyxia in our country.

\section{Conclusion}

The results of the interventions made in the first few minutes of life directly affect the quality of life, creating effects that will last a lifetime. Intervention of the newborn in the delivery room in the first minutes is extremely important in reducing neonatal deaths. The fact that nurses and midwives working in delivery rooms and neonatal intensive care units (NICU) pass through the neonatal resuscitation program and gain knowledge and experience in this field will be effective in reducing neonatal deaths. This research was applied to all nurses-midwives working in the obstetrics and maternity clinics of public hospitals in Adana, Turkey, who had received Neonatal Resuscitation Program (NRP) training, and sample selection was not conducted. The knowledge scores were found to be quite good considering that the participants of the NRP practitioner training course mostly took this course within $4-5$ years. It is recommended to systematically repeat with in-service training programs in order to acquire and practice these knowledges and skills.

\section{Acknowledgments}

This study was supported by Çukurova University Individual Research Project (number: TSA-2017-7740). This work was presented as a poster in International Conference on Nursing 2016 and its abstract was published in the Special Issue in the Madridge Journal of Nursing (MJN) (December 5-7, 2016, Dubai-UAE). This study was supported by Çukurova University Individual Research Project (number: TSA-2017-7740).

\section{Disclosure}

The authors declare no conflicts of interest in this work.

\section{References}

1. World Health Organization. Newborns: reducing mortality. Available from: http://www.who.int/mediacentre/factsheets/fs333/en/. Accessed September 25, 2018.

2. Çavuşoğlu H. Çocuk Sağlı̆̆ Hemşireliği. [Child Health Nursing]. 9 ed. Ankara: Ankara Sistem Ofset Printing House; 2012:57-110.

3. Özbaş S. Türkiye'de 2002, 2004 ve 2007 yıllarında gerçekleştirilen Yenidoğan canlandırma programı uygulayıcı eğitimlerinin belirlenen kalite kriterleri ve katılımcı geri bildirimlerine göre değerlendirilmesi. [Turkey in 2002, 2004 and Evaluated According to the Quality Criteria and Participant Feedback Determination of Realized Practitioners Trained in Neonatal Resuscitation Program in 2007]. Danışman: Seçil Özkan (Unpublished Thesis) [Yüksek Lisans Tezi]. Ankara: Gazi Üniversitesi Sağlık Bilimleri Enstitüsü; 2008:1-111.

4. Lawn JE, Cousens S, Zupan J. 4 million neonatal deaths: when? Where? Why? Lancet. 2005;365:891-900. doi:10.1016/S0140-6736(05)71048-5

5. Lawn JE, Osrin D, Adler A, et al. Four million neonatal deaths: counting and attribution of cause of death. Paediart Perinat Epidemiol. 2008;22 (5):410-416. doi:10.1111/j.1365-3016.2008.00960.x

6. Tezel B, Ilhan M, Günay İ, et al. Türkiye yenidoğan canlandırma programı (NRP) uygulayıcı kursları [Neonatal resuscitation program provider courses in Turkey] İzmir Dr. Behçet Uz Çocuk Hast. Dergisi. 2015;5(2):101-108. doi:10.5222/buchd.2015.101

7. Taşdelen E, Arvas A. Yenidoğan resüsitasyonu [Neonatal resuscitation]. Perinatoloji Dergisi. 1993;1(4):205-212.

8. Sütçüoğlu S, Tümer M, Meydan E, et al. Yenidoğanlarda Doğum Odası Resüsitasyon Uygulamaları ve Etkileyen Risk Faktörleri [Birth Room Resuscitation Practices and Affecting Risk Factors in Newborns]. SSK Tepecik Egitim Hastanesi Dergisi. 2003;3(13):163-169. doi:10.5222/ terh.2003.88046

9. Tekin N, Akşit A. Yenidoğan bebeğin doğum odasında resüsitasyonu [Resuscitation of newborn baby in delivery room]. Perinatoloji Dergisi. 2001;9(2):97-105.

10. Yılmaz D. Hemşirelere Verilen Kardiyopulmoner Resusitasyon Eğitiminin Bilgi Düzeyine Etkisi [The Effect of Cardiopulmonary Resuscitation on the Knowledge Level of Nurses] [Master Thesis, Atatürk Üniversitesi Sağlık Bilimleri Enstitüsü, Erzurum]. Danışman: Neziha Karabulut; 2013:1-91. 
11. Duran R, Aladağ N, Şen F, et al. Yenidoğan "Resüsitasyon” Program Kursu Sonrası Yenidoğan Hemşirelerinin Bilgi Kazanımları [Knowledge of Newborn Nurses After Newborn Resuscitation Program]. Türk Ped Ars. 2007;42:153-155.

12. Uçan S, Alparslan Ö. Hastanede çalışan ebelerin neonatal resüsitasyon konusundaki bilgileri [Information of midwives on neonatal resuscitation]. Yogun Bakim Hemsireligi Dergisi. 2015;19(1):7-14.

13. Neonatal Resuscitation Programı. Available from: http://cocukergen.thsk.saglik.gov.tr/daire-faaliyetleri/bebek-ve-cocuk-olumleri-onlenmesi/759yenido\%C4\%9Fan-canland\%C4\%B1 rma-program\%C4\%B1.html. Accessed May 8, 2017.

14. Bloom RS, Cropley C. Textbook of Neonatal Resuscitation. American Academy of Pediatrics, American Heart Association; 2000.

15. Ergenekon E, Koc E, Atalay Y, et al. Neonatal resuscitation course experience in Turkey. Resuscitation. 2000;45:225-227. doi:10.1016/S03009572(00)00179-9

16. Oswalt J, Boyce D. International nursing education: Istanbul, Turkey. J Pediatr Nurs. 2000;15(3):183-189. doi:10.1053/jn.2000.6024

17. Trevisanuto D, Ferrarese P, Cavicchioli P, et al. Knowledge gained by pediatric residents after neonatal resuscitation program courses. Pediatr Anesth. 2005;15:944-947. doi:10.1111/j.1460-9592.2005.01589.x

18. Wyllie J, Bruinenberg J, Roehr CC, Rüdiger M, Trevisanuto D, Urlesberger B. European Resuscitation Council guidelines for resuscitation 2015: section 7. Resuscitation and support of transition of babies at birth. Resuscitation. 2015;95:249-263.

19. Dorfsman ML, Menegazzi JJ, Wadas RJ, et al. Two-thumb vs. two-finger chest compression in an infant model of prolonged cardiopulmonary resuscitation. Acad Emerg Med. 2000;7(10):1077-1082. doi:10.1111/j.1553-2712.2000.tb01255.x

20. Akıllı BN, Cander B, Köylü R, et al. Kardiyopulmoner Resüsitasyonu Ne Kadar Biliyoruz? [How much do we know about cardiopulmonary resuscitation?]. J Acad Emerg Med. 2012;11:102-105. doi:10.5152/jaem.2012.007

21. Yılmaz LH, Yıldızdaş RD, Yıldızdaş YH, et al. Çocuklarda İleri Yaşam Desteği Güncel ve Kolay Yaklaşım Çocuklarda İleri Yaşam [Advanced life support in children current and easy approach]. Çocuk Acil Tip Ve Yogun Bakim Dernegi. 2015. Available from: https://suatbicer.files.wordpress. com/2017/05/ccca7icc87yad-kicc87tap-2015.pdf. Accessed February 15, 2022.

22. Summary of the main changes in the Resuscitation Guidelines ERC GUIDELINES 2015 Published by: European Resuscitation Council vzw, Emile Vanderveldelaan 35, 2845 Niel, Belgium; 2015. Available from: www.erc.edu. Accessed February 10, 2022.

23. Jukkala MA, Henly JS. Readiness for neonatal resuscitation: measuring knowledge, experience, and comfort level. Appl Nurs Res. 2007;20 (2):78-85. doi:10.1016/j.apnr.2006.01.006

24. Çınar ND, Güney R. Hemşirelerin yenidoğan resüsitasyonu konusundaki bilgilerinin değerlendirilmesi ve eğitim gereksinimlerinin belirlenmesi [Evaluation of nurses' knowledge about neonatal resuscitation and determination of training needs]. Yogun Bakim Dergisi. 2002;6(2):65-68.

25. Kattwinkel J, Perlman JM, Aziz K, et al. Part 15: neonatal resuscitation: 2010 American Heart Association Guidelines for Cardiopulmonary Resuscitation and Emergency Cardiovascular Care. Circulation. 2010;122:S909. doi:10.1161/CIRCULATIONAHA.110.971119

26. Watterberg KL, Aucott S, Benitz WE; American Academy of Pediatrics Committee on Fetus and Newborn; American College of Obstetricians and Cynecolo-gists Committee on Practise. The Apgar Score. Pediatrics. 2015;136(4):819-822. doi:10.1542/peds.2015-2651.

27. Katheria A, Rich W, Finer N. Electrocardiogram provides a continuous heart rate faster than oximetry during neonatal resuscitation. Pediatrics. 2012;130(5):1177-1181. doi:10.1542/peds.2012-0784.

28. T.C. Sağlık Bakanlığı Verileri, Sağlık İstatistik Yıllıkları [T.C. Health Ministry Data, Health Statistics Annuals]. Adana ili bebek ölüm bilgisi [Adana Province infant mortality information]; 2014.

Journal of Multidisciplinary Healthcare

\section{Dovepress}

\section{Publish your work in this journal}

The Journal of Multidisciplinary Healthcare is an international, peer-reviewed open-access journal that aims to represent and publish research in healthcare areas delivered by practitioners of different disciplines. This includes studies and reviews conducted by multidisciplinary teams as well as research which evaluates the results or conduct of such teams or healthcare processes in general. The journal covers a very wide range of areas and welcomes submissions from practitioners at all levels, from all over the world. The manuscript management system is completely online and includes a very quick and fair peer-review system. Visit http://www.dovepress.com/testimonials.php to read real quotes from published authors.

Submit your manuscript here: https://www.dovepress.com/journal-of-inflammation-research-journal 